УДК $615.11: 340.11 .5$

DOI https://doi.org/10.11603/2312-0967.2020.4.11542

\title{
ВИЗНАЧЕННЯ МІСЦЯ ФАРМАЦЕВТИЧНОГО ПРАВА В СУЧАСНІЙ СИСТЕМІ ПРАВА
} УКРАЇ̈И

\author{
А. А. Котвіцька, І. В. Кубарєва, А. В. Волкова, Г. Є. Болдарь, А. В. Черкашина \\ Національний фрармацевтичний університет Міністерства охорони здоров'я \\ України, Харків \\ socpharm@nuph.edu.ua
}

ІНФОРМАЦІЯ

Надійшла до редакції / Received: 27.10.2020

Після доопрацювання / Revised: 09.11.2020

Прийнято до друку / Accepted: 12.11.2020

\section{Ключові слова:}

фрармацевтичне право;

срармацевтичне законодавство; система права;

система законодавства; предмет правового регулювання; метод правового регулювання; медичне право;

система фрармацевтичного права; інститут фармацевтичного права.

\begin{abstract}
АНОТАЦІЯ
Мета роботи. Визначення місця фрармацевтичного права в системі права України, аналіз його предмета, методу та системи на підставі загальнотеоретичних розробок про галузь права та законодавства.

Матеріали і методи. Дослідження проведено на основі опрацювання наукової та навчальної літератури, нормативно-правових актів. Використано методи аналізу, синтезу, узагальнення, системно-структурний, формальнологічний, порівняно-правовий, тлумачення правової норми.

Результати й обговорення. Встановлено, що у вітчизняній спеціальній літературі спостерігається недостатня кількість праць, присвячених вивченню юридичної природи срармацевтичного права. Обговорення цієї проблеми більш активно здійснюється зарубіжними науковцями, ніж українськими. Привертає увагу факт відсутності єдиного підхіду до розуміння предмета та методу фрармацевтичного права. Ці питання іноді висвітлюються у загальнотеоретичних роботах у рамках наукової дискусії про можливість існування комплексних галузей права в системі права. Зроблено висновок, що вчені не досягли загальної точки зору щодо галузевої належності фрармацевтичного права та законодавства. Частина дослідників вважають фармацевтичне право складовою частиною (підгалуззю) медичного або економічного (господарського) права, а інші визначають як самостійну комплексну галузь права або законодавства.

Висновки. Обґрунтована наукова позиція про те, що в сучасних умовах склалися підстави вважати фрармацевтичне право самостійною комплексною галуззю права, предметом якої виступають управлінські, майнові та немайнові відносини, що виникають під час здійснення фрармацевтичної діяльності, для регулювання яких використовуються методи субординації (імперативний) та координації (диспозитивний). Запропоновано поділ системи фрармацевтичного права на Загальну та Особливу частини, розкрито інститути кожної з них.
\end{abstract}

Вступ. Належне правове регулювання фрармацевтичної діяльності $є$ запорукою втілення у практику державотворення поступального руху України як соціальної правової держави, оскільки якісна фрармацевтична допомога є невід'ємною складовою системи охорони здоров'я (О3). Особливо важливого зна- чення набуває забезпечення збалансованого нормативно-правого регулювання суспільних відносин, які виникають у фрармацевтичному секторі галузі охорони здоров'я, що пояснюється визнанням у всіх демократичних країнах того, що людина, її життя та здоров'я є найвищою соціальною цінністю.

ISSN 2312-0967. Pharmaceutical review. 2020. № 4 


\section{Pharmaceutical legislation}

Аналіз останніх досліджень і публікацій свідчить про те, що френомен фрармацевтичного права як галузі права та законодавства останнім часом став предметом низки наукових досліджень [1-6]. Привертає увагу фракт, що питання визначення предмета та методу фрармацевтичного права також висвітлюються у загальнотеоретичних роботах у рамках наукової дискусії щодо можливості існування комплексних галузей права в системі права, нова хвиля якої розгорнулась останнім часом [7, 8].

Проте у вітчизняній спеціальній літературі спостерігається недостатня кількість праць, присвячених вивченню юридичної природи фрармацевтичного права. Різняться думки учених щодо віднесення фармацевтичного права до самостійної комплексної галузі чи законодавства. Відповідно актуальним є розгляд предмета фрармацевтичного права, його методу та системи.

Мета роботи - визначити місце фрармацевтичного права в системі права України, здійснити аналіз його предмета, методу та системи на підставі загальнотеоретичних розробок про галузь права та законодавства.

Матеріали і методи. Дослідження проведено на основі опрацювання дисертацій, монографій, підручників, навчальних посібників, наукових статей, тез доповідей та нормативно-правових актів. Авторами у процесі дослідження використано загальнонаукові та спеціальні методи дослідження, зокрема, діалектичний, аналізу, синтезу, узагальнення, системно-структурний, формально-логічний, порівняно-правовий.

Результати й обговорення. На підставі аналізу основних наукових позицій різних учених щодо галузевої належності та предмета фрармацевтичного права можна стверджувати, що ці питання на сьогодні $€$ дискусійними - вченими не вироблено єдиного підходу до розуміння місця фрармацевтичного права в національній правовій системі, його предмета та методу тощо. Встановлено, що фрармацевтичне право розглядається як самостійна комплексна галузь права, як складова частина медичного права та як складова частина економічного права (табл.).

Відповідно, актуальним є пошук відповіді на питання чи $є$ підстави вважати сьогодні в Україні фрармацевтичне право самостійною комплексною галуззю права, оскільки суспільні відносини, які складаються у фрармації, входять до предмета регулювання інших галузей права.

Загальновідомим є традиційне розуміння галузі права як відносно самостійної (автономної) сукупності юридичних норм, яка регулює якісно однорідну сореру (рід) суспільних відносин. Класичними визна-

Таблиця

Результати узагальнення аналізу літературних джерел щодо галузевої належності фармацевтичного права

\begin{tabular}{|c|c|c|}
\hline № & Наукова позиція & Літературне джерело \\
\hline 1 & 2 & 3 \\
\hline \multicolumn{3}{|c|}{ Фармацевтичне право є самостійною комплексною галуззю права } \\
\hline 1 & $\begin{array}{l}\text { Фармацевтичне право є сукупністю правових норм, які регу- } \\
\text { люють суспільні відносини у фрармацевтичному секторі галузі } \\
\text { охорони здоров'я [1, с. 59] }\end{array}$ & $\begin{array}{l}\text { Основи права та законодавства у } \\
\text { фармації : нац. підруч. для студентів } \\
\text { ВНЗ / А. А. Котвіцька та ін. ; за ред. } \\
\text { А. А. Котвіцької. - Харків : НФаУ : Золоті } \\
\text { сторінки, 2016. - } 528 \text { с. }\end{array}$ \\
\hline 2 & $\begin{array}{l}\text { Фармацевтичне право є системою загальнообов'язкових пра- } \\
\text { вових норм (сукупності взаємоузгоджених міжнародних та на- } \\
\text { ціональних міжгалузевих чи тільки галузевих підзаконних актів, } \\
\text { настанов, директив, кодексів фрармацевтичної етики і деонтоло- } \\
\text { гії), які регулюють правовідносини учасників світового чи тільки } \\
\text { регіонального фрармацевтичного ринку [2, с. 1755] }\end{array}$ & $\begin{array}{l}\text { Фармацевтична енциклопедія / голова } \\
\text { ред. ради та автор передмови В. П. Чер- } \\
\text { них. - 3-те вид., переробл. і доп. - К. : } \\
\text { МОРІОН, 2016. - } 1952 \text { с. }\end{array}$ \\
\hline 3 & $\begin{array}{l}\text { Фармацевтичне право є сукупністю правових норм, які регулю- } \\
\text { ють суспільні відносини між учасниками фрармацевтичного рин- } \\
\text { ку, що виникають у процесі реалізації права на фрармацевтичну } \\
\text { діяльність [2, с. } 1755]\end{array}$ & $\begin{array}{l}\text { Фармацевтична енциклопедія / голова } \\
\text { ред. ради та автор передмови В. П. Чер- } \\
\text { них. - 3-те вид., переробл. і доп. - К. : } \\
\text { МОРІОН, 2016. - } 1952 \text { с. }\end{array}$ \\
\hline 4 & $\begin{array}{l}\text { Фармацевтичне право - комплексна галузь права, яка регулює } \\
\text { відносини з приводу розробки, експертизи, державної реєстра- } \\
\text { ції, стандартизації, контролю якості та безпеки, виробництва } \\
\text { (виготовлення), зберігання, перевезення, маркетингу та рекла- } \\
\text { ми, обігу, розподілу, призначення, відпуску, вживання та ути- } \\
\text { лізації фрармацевтичних продуктів - лікарських засобів (Л3), а } \\
\text { також яка регулює правове становище об'єктів інтелектуальної } \\
\text { власності у сфрері фрармацевтики й права на них [3, с. 39] }\end{array}$ & $\begin{array}{l}\text { Понкин И. В. Фармацевтическое пра- } \\
\text { во / И. В. Понкин, А. А. Понкина. - М. : } \\
\text { ГЭОТАР - Медиа, 2017. - } 144 \text { с. }\end{array}$ \\
\hline
\end{tabular}

ISSN 2312-0967. Фармацевтичний часопис. 2020. № 4 
Фармацевтичне законодавство

Pharmaceutical legislation

Продовження табл.

\begin{tabular}{|c|c|c|}
\hline 1 & 2 & 3 \\
\hline 5 & $\begin{array}{l}\text { 3'явившись у межах медичного (біомедичного) права, фрарма- } \\
\text { цевтичне право не може не зберігати з ним генетичного зв'язку. } \\
\text { Проте предметне поле фармацевтичного права не повною } \\
\text { мірою збігається з предметним полем медичного права, не по- } \\
\text { глинається ним [4, с. 58]. Фармацевтичне право регулює відо- } \\
\text { соблену частину сорери виробництва та торгівлі л3, а також } \\
\text { правовідносини по обігу біомедичних клітинних продуктів, ме- } \\
\text { дичних виробів, біологічно активних добавок, замінників грудно- } \\
\text { го (жіночого) молока [4, с. 59]. }\end{array}$ & $\begin{array}{l}\text { Мохов А. А. Фармацевтическое право } \\
\text { как френомен // Актуальные проблемы } \\
\text { российского права. - 2017. - № 1. - } \\
\text { С. 54-62. }\end{array}$ \\
\hline \multicolumn{3}{|c|}{ Фармацевтичне право є складовою частиною медичного права } \\
\hline 6 & $\begin{array}{l}\text { Фармацевтичне право - це нова галузь права. Предметом її } \\
\text { регулювання є відносини, які виникають у сорері організації } \\
\text { забезпечення Л3 та фрармацевтичної діяльності. Зараз фрарма- } \\
\text { цевтичне право знаходиться тільки на початку свого розвитку, } \\
\text { тому на період свого становлення може вважатись підсистемою } \\
\text { медичного права [5, с. 23]. }\end{array}$ & $\begin{array}{l}\text { Мельникова О. А. Понятие фрармацевти- } \\
\text { ческого права / О. А. Мельникова // Меди- } \\
\text { цинское право. - 2014. - № 4. - С. 21-24. }\end{array}$ \\
\hline 7 & $\begin{array}{l}\text { Предмет медичного права складають суспільні відносини, які } \\
\text { виникають у процесі здійснення медичної й фрармацевтичної ді- } \\
\text { яльності }[9, \text { с. 122] }\end{array}$ & $\begin{array}{l}\text { Дешко Л. Про галузеву належність медич- } \\
\text { ного права України / Л. Дешко // Право } \\
\text { України. - 2006. - № 1. - С. 120-124. }\end{array}$ \\
\hline 8 & $\begin{array}{l}\text { Медичне право як комплексна галузь права охоплює виробни- } \\
\text { цтво ЛЗ і виробів медичного призначення [3, с. 8]. Забезпечен- } \\
\text { ня ЛЗ належить до основних інститутів медичного права [10, с. } \\
122]\end{array}$ & $\begin{array}{l}\text { Стеценко С. Г., Стеценко В. Ю., Сеню- } \\
\text { та І. Я. Медичне право України : підруч. / } \\
\text { За заг. ред. Д. юрид. н., проф. С. Г. Сте- } \\
\text { ценка. - К. : Всеукраїнська асоціація ви- } \\
\text { давців «Правова єдність», 2008. - } 507 \text { с. }\end{array}$ \\
\hline 9 & $\begin{array}{l}\text { Предметом медичного права є правовідносини у сфері надання } \\
\text { медичного обслуговування. До їх складу входять: 1) правовід- } \\
\text { носини у сорері надання медичної допомоги; 2) правовідносини } \\
\text { у сфрері діяльності, тісно пов'язаної з медичною допомогою. } \\
\text { Складовою частиною останніх є правовідносини щодо вироб- } \\
\text { ництва Л3, оптової та роздрібної торгівлі Л3, імпорту ЛЗ (крім } \\
\text { активних фрармацевтичних інгредієнтів) [11, с. 130] }\end{array}$ & $\begin{array}{l}\text { Сенюта І. Я. Цивільні правовідносини } \\
\text { у ссрері надання медичної допомоги в } \\
\text { Україні: питання теорії і практики : дис. ... } \\
\text { Д. юрид. наук : спец. 12.00.03 / Сенюта } \\
\text { Ірина Ярославівна. - К., 2018. - } 500 \text { с. }\end{array}$ \\
\hline \multicolumn{3}{|c|}{ Фармацевтичне право є складовою частиною економічного права } \\
\hline 10 & $\begin{array}{l}\text { Фармацевтичне право зараз знаходиться на етапі свого станов- } \\
\text { лення. Воно є невід'ємною складовою частиною економічного } \\
\text { права. Фармацевтичне право має генетичну спільність з пра- } \\
\text { вом медичним, адже лікарське забезпечення є важливою скла- } \\
\text { довою медичної допомоги [6, с. 39] }\end{array}$ & $\begin{array}{l}\text { Андреева Л. В. Правовые основы об- } \\
\text { ращения лекарственных препаратов для } \\
\text { медицинского потребления : монографрия } \\
\text { / Отв. ред. Д. юрид. Н., проф. Мохов А. А., } \\
\text { д. мед. н. Олесир Ю. В. - ООО «Про- } \\
\text { спект», 2017. - } 261 \text { с. }\end{array}$ \\
\hline
\end{tabular}

чальними критеріями поділу права на галузі є предмет, під яким розуміють сукупність однорідних суспільних відносин, що урегульовані нормами права, та метод правового регулювання [12].

Сьогодні у фрармації виникає значна кількість різних суспільних відносин, зокрема управлінських (контроль за додержанням ліцензійних умов, за якістю Л3, стандартизація, сертифікація, ціноутворення тощо); майнових, що складаються, наприклад, у процесі здійснення господарської діяльності з виробництва, торгівлі, імпорту, експорту, промоції, дистрибуції, реімбурсації вартості ЛЗ та ін.; немайнових, які виникають, коли лз або певні технології (розробки) стають об'єктом права інтелектуальної власності (на- приклад, реєстрації, патентування тощо), під час проведення доклінічних досліджень ЛЗ тощо. На наш погляд, весь цей комплекс суспільних відносин, які виникають у фармацевтичному секторі галузі О3, і складає предмет фрармацевтичного права.

Суб'єктами правовідносин у сфері фрармацевтичної діяльності є: держава в особі компетентних органів, які уповноважені контролювати різні аспекти фрармацевтичної діяльності, лікарі, фрармацевти, провізори, імпортери, експортери, виробники, власники реєстраційних посвідчень на ЛЗ, дистриб'ютори, промоутери, пацієнти тощо.

Отже, не можна погодитись з прихильниками думки про існування фрармацевтичного права як складо-

ISSN 2312-0967. Pharmaceutical review. 2020. № 4 
вої права медичного, цивільного або господарського, оскільки очевидно, що правовідносини щодо виробництва, оптової та роздрібної реалізації, імпорту Л3, не єдині, які фрормуються у фрармацевтичному секторі. При цьому не викликає заперечення той оракт, що між фрармацевтичним та медичним правом існують тісні генетичні зв'язки, які зумовлені тим, що обидві галузі регулюють відносини, які виникають у процесі реалізації права людини на охорону здоров'я.

Проведений аналіз свідчить про існування у фармацевтичного права самостійного предмета регулювання. Сьогодні ця галузь права інтегрує правові норми, що регулюють суспільні відносини, які виникають у процесі реалізації права людини на охорону здоров'я та фрармацевтичне забезпечення в усіх його проявах з урахуванням галузевої регламентації.

Для вирішення питання про місце фрармацевтичного права у системі права України необхідно також розглянути особливості методу правового регулювання, який визначають як сукупність прийомів і засобів впливу на суспільні відносини [12]. У теорії права загальновизнано, що основними прийомами регулювання суспільних відносин є методи субординації та координації. Метод субординації (імперативний) ґрунтується на відносинах влади й підпорядкування, на правовій нерівності сторін. Він застосовується при регулюванні відносин, в яких однією зі сторін виступає орган держави, наділений владними повноваженнями. Це метод влади та підпорядкування. Як відомо, найвиразніше зазначений метод представлено у таких галузях права, як адміністративне і фрінансове, тобто у публічному праві $[7,12,13]$.

Для приватного права характерний інший метод правового регулювання - метод координації (диспозитивний), що допускає рівноправність і незалежність учасників відносин, надає їм можливість у рамках, установлених законом, самостійно визначати взаємні права й обов'язки. Зазначений метод найбільш властивий цивільному праву $[7,12,13]$.

Однак вже давно в системі права виділяють так звані комплексні галузі, які використовують обидва вищевказані методи правового регулювання. На думку Дудник Р. М., основною рисою комплексних галузей права $€$ входження до предмета їх регулювання кола суспільних відносин, що виокремились із різних галузей права, при цьому мають свою специфіку, що зумовлює їх автономність. Відповідно виділяються такі особливості комплексної галузі права: регулює різнорідні відносини; складається із норм різних галузей права; використовуються різні методи правового регулювання [13].

Із характеристики відносин, які регулюються фрармацевтичним правом, випливає, що у цій галузі використовують обидва «класичні» методи правового регулювання. Так, при регулюванні господарсько-договірних відносин між суб'єктами фрармацевтичної діяльності (наприклад, між аптеками та дистриб'юторами щодо поставки продукції) або відносин між пацієнтом і провізором переважним $€$ метод координації. В регулюванні державного контролю (нагляду) за різними напрямами дотримання законодавства суб'єктами фрармацевтичної діяльності, ліцензування всіх її видів, стандартизації та сертифрікації, реімбурсації вартості ЛЗ домінуючим буде метод субординації.

Безумовно, вітчизняна система права постійно розвивається. Результатом процесу фрормування правової системи України в напрямку розвитку соціальної правової держави, охорони й захисту прав і свобод людини є втілення у правову площину нових теоретичних конструкцій, фрормування нових галузей права [12]. Перелік галузей права не $є$ постійним, оскільки визначити його неможливо 3 об'єктивних причин - через розвиток права, притаманний йому динамічний характер, зумовлений цивілізаційними процесами у державі, змінами соціально-економічних умов тощо.

Такий підхід, на нашу думку, пояснюється тим, що всі процеси, які відбуваються у правовій доктрині, повинні створювати оптимальні умови для суспільноекономічного розвитку та відповідати своєму історичному часу. За твердженням Г. П. Курдюк ознаки, які допустимі для відокремлення сукупності норм у галузь права в одних історичних умовах, можуть бути недопустимими (незатребуваними) в інших [7]. Аналогічної точки зору дотримується й профресор С. Г. Дробязко, який вказує, що вдосконалення галузей права та галузей законодавства, підвищення його якості несумісне 3 порушенням об'єктивних законів розвитку права, його функціонування, особливо щодо основної закономірності - постійного стимулювання правовими засобами соціально корисної активності суб'єктів правових відносин [8].

Необхідно погодитись 3 тим, що на сучасному етапі процес виникнення нових галузей права відбувається на рівні саме комплексних галузей права, оскільки фрундаментальні (конституційне), основні (адміністративне, кримінальне, цивільне, трудове) та просрілюючі або базові (сімейне, митне, кримінальновиконавче) галузі уже сорормовано. Правове життя сучасної України підтверджує необхідність виокремлення у системі права комплексних галузей, оскільки сучасна практика переконливо свідчить про те, що крім галузей права, які упорядковують однорідні суспільні відносини, реально існує регламентація комплексних, різнорідних соціальних відносин у відповідних життєво важливих сорерах, що потребують правового регулювання. Саме правове регулювання різноманітних відносин сприяло фрормуванню комплексних галузей українського права [13].

На сучасному етапі у правовій системі України виділяють вже достатню кількість самостійних комплексних галузей права, в яких застосовується як імперативний, так і диспозитивний методи, зокрема госпо-

ISSN 2312-0967. Фармацевтичний часопис. 2020. № 4 
дарське, банківське, податкове, інфрормаційне, екологічне, медичне тощо. На наш погляд, до цієї групи доцільно віднести й фрармацевтичне право, яке на сьогодні знаходиться на новій стадії свого розвитку.

Формування фрармацевтичного права як галузі пояснюється необхідністю особливого законодавчого регулювання багатоаспектних суспільних відносин у галузі фрармації, а також ії̈ специфрічним соціальноекономічним значенням. Відповідно, фрармацевтичне законодавство, як зовнішня фрорма існування фрармацевтичного права, $є$ новою галуззю в системі законодавства України, яке за своєю фрормою являє собою сукупність нормативно-правових актів різної юридичної сили, а за своїм нормативним змістом $є$ сукупністю правових норм, що регулюють фрармацевтичну діяльність, які на сьогодні містяться у різноманітних законодавчих актах різногалузевої спрямованості (зокрема, положення конституційного, адміністративного, цивільного, господарського, митного, фрінансового, трудового, екологічного, кримінального права тощо).

Щодо системи фрармацевтичного права, то, на наш погляд, вона складається з юридичних норм Загальної та Особливої частин (рис.).

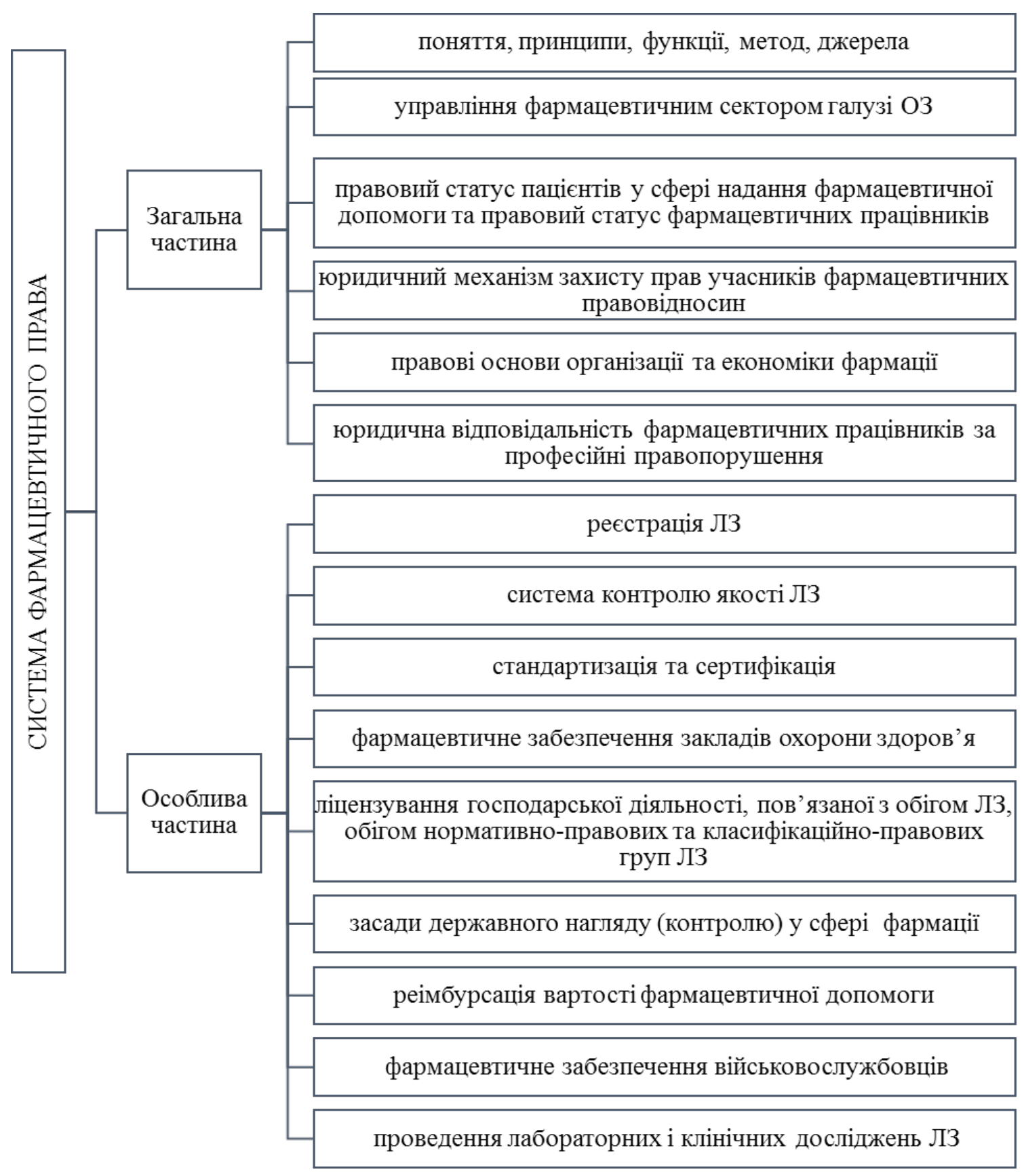

Рис. Система фрармацевтичного права України.

ISSN 2312-0967. Pharmaceutical review. 2020. № 4 
Висновки. Результати проведеного дослідження свідчать, що науковою спільнотою не вироблено єдиного підходу до розуміння місця фрармацевтичного права у національній системі права, а також його предмета та методу. На думку одних вчених, фрармацевтичне право утворює самостійну комплексну галузь права та (або) комплексну галузь законодавства, інші науковці вважають його складовою частиною різних галузей права, зокрема медичного або економічного (господарського) права.

На підставі аналізу особливостей кола суспільних відносин, які регулюються правовими нормами, а також засобів впливу на них, встановлено, що сьогодні $€$ підстави вважати фрармацевтичне право самостійною комплексною галуззю права. Обґрунтовано, що фрармацевтичне право має власні предмет та набір методів правового регулювання, а також свій комплекс нормативно-правових актів.

3'ясовано, що предметом правового регулювання срармацевтичного права виступають управлінські, майнові та немайнові відносини, що виникають під час здійснення фрармацевтичної діяльності. Доведе- но, що фрармацевтичне право як галузь права - це сукупність правових норм, які регулюють суспільні відносини у фрармацевтичному секторі галузі охорони здоров'я.

Зазначено, що єдину систему фрармацевтичного права України складають дві підсистеми: норми Загальної та Особливої частини, спрямовані на виконання спільного завдання - правового забезпечення розвитку та соціальної орієнтації фрармацевтичного сектора галузі охорони здоров'я.

Проведене дослідження не вичерпує всіх аспектів проблеми галузевої диференціації фрармацевтичного права. Ґрунтовної наукової розробки потребують питання його принципів, фрункціональних зв'язків із суміжними галузями (зокрема медичним, господарським, трудовим, адміністративним, кримінальним тощо), а також правового статусу фрармацевтичного працівника як суб'єкта правовідносин, які виникають у зв'язку з його професійною діяльністю.

Конфлікт інтересів: відсутній.

Conflicts of interest: authors have no conflict of interest to desclare.

\title{
DETERMINING THE POSITION OF PHARMACEUTICAL LAW IN THE MODERN LEGAL SYSTEM OF UKRAINE
}

\author{
A. A. Kotvitska, I. V. Kubarieva, A. V. Volkova, G. E. Boldar, A. V. Cherkashyna \\ National University of Pharmacy of the Ministry of Health of Ukraine, Kharkiv \\ socpharm@nuph.edu.ua
}

The aim of the work. To determine the position of pharmaceutical law in the legal system of Ukraine, analyze its subject, method, and system based on general theoretical developments about the field of law and legislation.

Materials and Methods. The research is based on the study of scientific and educational literature, legal acts. The methods of analysis, synthesis, generalization, system-structural, formal-logical, comparative-legal, and interpretation of the legal norm are used.

Results and Discussion. It is established that in domestic specialized literature there is an insufficient number of works devoted to the study of the legal nature of pharmaceutical law. The discussion of this problem is more actively carried out by foreign scientists than by Ukrainian ones. It is noteworthy that today there is no unified approach to understanding the subject and method of pharmaceutical law. These issues are sometimes covered in general theoretical works as a part of scientific discussion about the possibility of the existence of complex branches of law in the legal system.

It is concluded that scientists have not reached a common point of view regarding the industry affiliation of pharmaceutical law and legislation. Some researchers consider pharmaceutical law to be an integral part (sub-branch) of medical or economic (economic) law, while others define it as an independent complex branch of law or legislation.

Conclusions. A scientific position has been justified that in modern conditions there are reasons to believe the pharmacy law as an independent complex branch of law, a subject of which are managerial, economic and moral relations arising during implementation of the pharmaceutical activity, to control which uses techniques of subordination (imperative) and coordination (dispositive). The division of the pharmaceutical law system into General and Special parts is proposed, and concepts of each of them are revealed.

Key words: pharmaceutical law; pharmaceutical legislation; system of law; legislation system; a subject of legal regulation, method of legal regulation; medical law; system of pharmaceutical law; pharmaceutical law concept.

ISSN 2312-0967. Фармацевтичний часопис. 2020. № 4 


\title{
ОПРЕДЕЛЕНИЕ МЕСТА ФАРМАЦЕВТИЧЕСКОГО ПРАВА В СОВРЕМЕННОЙ СИСТЕМЕ ПРАВА УКРАИНЫ
}

\author{
А. А. Котвицкая, И. В. Кубарева, А. В. Волкова, Г. Е. Болдарь, А. В. Черкашина \\ Национальный фрармацевтический университет Министерства здравоохранения Украины, Харьков \\ socpharm@nuph.edu.ua
}

\begin{abstract}
Цель работы. Определить место фрармацевтического права в системе права Украины, проанализировать его предмет, метод и систему на основании общетеоретических разработок об отрасли права и законодательства.

Материалы и методы. Исследование проведено на основе изучения научной и учебной литературы, нормативноправовых актов. Использованы методы анализа, синтеза, обобщения, системно-структурный, формальнологический, сравнительно-правовой, толкования правовой нормы.

Результаты и обсуждение. Установлено, что в отечественной специальной литературе наблюдается недостаточное количество работ, посвященных изучению юридической природы фрармацевтического права. Обсуждение этой проблемы более активно осуществляется зарубежными учеными, нежели украинскими. Обращает на себя внимание тот фракт, что на сегодня отсутствует единый подход к пониманию предмета и метода фрармацевтического права. Эти вопросы иногда освещаются в общетеоретических работах в рамках научной дискуссии о возможности существования комплексных отраслей права в системе права. Сделано вывод о том, что учеными не достигнуто общей точки зрения относительно отраслевой принадлежности фрармацевтического права и законодательства. Одни исследователи считают фрармацевтическое право составной частью (подотраслью) медицинского или экономического (хозяйственного) права, а другие определяют как самостоятельную комплексную отрасль права либо законодательства.

Выводы. Обоснована научная позиция о том, что в современных условиях сложились основания считать фрармацевтическое право самостоятельной комплексной отраслью права, предметом которой выступают управленческие, имущественные и неимущественные отношения, возникающие во время осуществления фармацевтической деятельности, для регулирования которых используются методы субординации (императивный) и координации (диспозитивный). Предложено деление системы фрармацевтического права на Общую и Особенную части, раскрыто институты каждой из них.
\end{abstract}

Ключевые слова: фрармацевтическое право; фрармацевтическое законодательство; система права; система законодательства; предмет правового регулирования; метод правового регулирования; медицинское право; система фрармацевтического права; институт фрармацевтического права.

\section{Список бібліографрічних посілань}

1. Основи права та законодавства у фрармації : нац. підруч. для студентів ВН3 / А. А. Котвіцька та ін. ; за ред. А. А. Котвіцької. Харків : НФаУ : Золоті сторінки, 2016. 528 c.

2. Фармацевтична енциклопедія / НАН України, НАМН України, НФаУ ; ред. рада: В. П. Черних (голова), І. М. Перцев ; ред.-упоряд.: С. В. Андрущенко, С. А. Нежуріна, Д. В. Литкін. 3-тє вид., допов. Київ : MOPIOH, 2016. 1952 c.

3. Понкин И. В., Понкина А. А. Фармацевтическое право. Москва : ГЭОТАР-Медиа, 2017. 144 с.

4. Мохов А. А. Фармацевтическое право как феномен. Актуальные проблемы российского права. 2017. № 1. C. 54-62.

5. Мельникова О. А. Понятие фрармацевтического права. Медицинское право. 2014. № 4. С. 21-24. URL: http://lawinfo.ru/catalog/6653/6735/4/ (дата обращения: 20.09.2020).

6. Андреева Л. В. Правовые основы обращения лекарственных препаратов для медицинского потребления : моногр. / отв. ред. А. А. Мохов, Ю. В. Олефир. Москва : Проспект, 2017. 256 с. URL: https://books.google.com.ua/books?id=ggZODg
AAQBAJ\&pg=PT309\&lpg=РТ309 (дата обращения: 20.09.2020).

7. Курдюк Г. П. Отрасль права как элемент системы права (Теоретико-правовое исследование) : дис. ... канд. юрид. наук : 12.00.01 : Краснодар, 2004. 221 с. URL: http://www.dslib.net/teoria-prava/otrasl-pravakak-jelement-sistemy-prava.html (дата обращения: 20.09.20).

8. Дробязко С. Г. Отрасли права и отрасли законодательства в правовой системе Республики Беларусь и их совершенствование. Право в современном белорусском обществе: сб. науч. тр. / Нац. центр законодат. и правов. исслед. Респ. Беларусь. Минск : Право и экономика, 2010. Вып. 5. C. 11-22.

9. Дешко Л. Про галузеву належність медичного права України. Право України. 2006. № 1. С. 120-124.

10. Стеценко С. Г., Стеценко В. Ю., Сенюта І. Я. Медичне право України : підручник / за ред. С. Г. Стеценка. Київ : Всеукраїн. асоціація видавців «Правова єдність», 2008. 507 с.

11. Сенюта І. Я. Цивільні правовідносини у сорері надання медичної допомоги в Україні: питання

ISSN 2312-0967. Pharmaceutical review. 2020. № 4 
теорії і практики : дис. ... д-ра юрид. наук : 12.00 .03 / Національна Академія правових наук України; Науково-дослідний інститут приватного права і підприємництва імені академіка Ф. Г. Бурчака : Київ, 2018. 500 c.

\section{References}

1. Kotvitska AA, Kubarieva IV, Surikov OO. Fundamentals of law and legislation in pharmacy. [Основи права та законодавства у фрармації: нац. підруч. для студентів ВН3] Kharkiv: NFaU: Zoloti storinky; 2016. Ukrainian.

2. Chernykh VP, Pertsev IM, Andrushchenko SV, Nezhurina SA, Lytkin DV, editors. Pharmaceutical encyclopedia, $3^{\text {rd }}$ ed. [Фармацевтична енциклопедія] Kyiv: MORION; 2016. Ukrainian.

3. Ponkin IV, Ponkina AA. Pharmaceutical law. [Фармацевтическое право] Moscow: GJeOTAR-Media; 2017. Russian.

4. Mohov AA. [Pharmaceutical law as a phenomenon]. Aktualnyye problemy rossiyskogo prava. 2017;1: 5462. Russian.

5. Melnikova OA. [Pharmaceutical law concept]. Meditsinskoe pravo. 2014;4: 21-4. Russian.

6. Andreeva LV. Legal basis for circulation of medicinal products for medical consumption. [Правовые основы обращения лекарственных препаратов для медицинского потребления: моногр] Mokhov AA, Olefir YuV, editors. Moscow: Prospekt; 2017. Available from: https://books.google.com.ua/books?id=ggZ0Dg AAQBAJ\&pg=PT309\&lpg=PT309. Russian.
12. Скакун О. Ф. Теорія права і держави : підручник. 4-е вид. - К. : Алерта, 2016. 524 с.

13. Дудник Р. М. Галузева дисреренціація українського права : поняття, рівні і тенденції розвитку : дис. ... канд. юрид. наук : 12.00.01 / Національний ун-т «Одеська юридична академія» : Одеса, 2016. 221 с.

7. Kurdiuk GP. [Branch of law as an element of the legal system (Theoretical and legal research)]. Dissertation. Krasnodar; 2004. 221 p. Available from: http://www. dslib.net/teoria-prava/otrasl-prava-kak-jelement-sistemy-prava.html. Russian.

8. Drobiazko SG. [Branches of law and branches of legislation in the legal system of the Republic of Belarus and their improvement]. Semenkov VI, editor. Pravo V sovremennom belorusskom obshhestve. Minsk: Pravo i ekonomika; 2010;5: 11-22. Russian.

9. Deshko L. [On the branch affiliation of medical law of Ukraine]. Pravo Ukrainy. 2006;1: 120-4. Ukrainian.

10. Stetsenko SH, Stetsenko VYu, Seniuta IYa. Medical law of Ukraine. [Медичне право України: підручник] Kyiv: Vseukrain. asotsiatsiia vydavtsiv "Pravova yednist"; 2008. 507 p. Ukrainian.

11. Seniuta IYa. [Civil legal relations in the field of medical care in Ukraine: issues of theory and practice]. Dissertation. Kyiv; 2018. 500 p. Ukrainian.

12. Skakun OF. Theory of state and law. [Теорія права і держави: підручник. 4-е вид.] Kyiv: Alerta; 2016. Ukrainian.

13. Dudnyk RM. [Industry differentiation Ukrainian law: concept, levels and trends]. Dissertation. Odesa; 2016. 221 p. Ukrainian.

\section{Інформація про авторів}

Котвіцька А. А. - д. фрармац. наук, профресор, заслужений діяч науки і техніки України, ректор, професор кафедри соціальної фрармації, Національний фрармацевтичний університет Міністерства охорони здоров'я України, Харків, Україна. E-mail: rector@nuph.edu.ua, ORCID: 0000-0002-6650-1583

Кубарєва I. В. - канд. фрармац. наук, доцент, проректор з науково-педагогічної роботи, доцент касредри соціальної фрармації, Національний фрармацевтичний університет Міністерства охорони здоров'я України, Харків, Україна. E-mail: inna.kubarieva@gmail.com, ORCID 0000-0001-6617-2575

Волкова А. В. - канд. фрармац. наук, доцент, завідувачка кафедри соціальної фрармації, Національний фрармацевтичний університет Міністерства охорони здоров'я України, Харків, Україна. E-mail: a.volkova@nuph.edu. ua, ORCID 0000-0003-2781-5407

Болдарь Г. Є. - канд. юрид. наук, доцент, доцент кафедри соціальної фармації, Національний фрармацевтичний університет Міністерства охорони здоров'я України, Харків, Україна. E-mail: galina_boldar@ukr.net, ORCID 00000001-8497-4977

Черкашина А. В. - канд. фрармац. наук, доцент, доцент кафедри соціальної фармації, Національний фрармацевтичний університет Міністерства охорони здоров'я України, Харків, Україна. E-mail: alinacherkashyna85@gmail.com, ORCID 0000-0003-2103-5096

\section{Information about the authors}

Kotvitska A. A. - DSc (Pharmacy), Professor, Honored Worker of Science and Technology of Ukraine, Rector, Professor of the Department of Social Pharmacy, National University of Pharmacy of the Ministry of Health of Ukraine, Kharkiv, Ukraine, e-mail: rector@nuph.edu.ua, ORCID: 0000-0002-6650-1583

Kubarieva I. V. - PhD (Pharmacy), Associate Professor, Vice-Rector for scientific and pedagogical (educative) work, Associate Professor of the Department of Social Pharmacy, National University of Pharmacy of the Ministry of Health of Ukraine, Kharkiv, Ukraine, e-mail: inna.kubarieva@gmail.com, ORCID 0000-0001-6617-2575

ISSN 2312-0967. Фармацевтичний часопис. 2020. № 4 
Volkova A. V. - PhD (Pharmacy), Associate Professor, Chief of the Department of Social Pharmacy, National University of Pharmacy of the Ministry of Health of Ukraine, Kharkiv, Ukraine, e-mail: a.volkova@nuph.edu.ua, ORCID 0000-00032781-5407

Boldar G. E. - PhD (Law), Associate Professor, Associate Professor of the Department of Social Pharmacy, National University of Pharmacy of the Ministry of Health of Ukraine, Kharkiv, Ukraine, e-mail: galina_boldar@ukr.net, ORCID 00000001-8497-4977

Cherkashyna A. V. - PhD (Pharmacy), Associate Professor, Associate Professor of the Department of Social Pharmacy, National University of Pharmacy of the Ministry of Health of Ukraine, Kharkiv, Ukraine, e-mail: alinacherkashyna85@gmail. com, ORCID 0000-0003-2103-5096 